\title{
PRAME wt Allele
}

National Cancer Institute

\section{Source}

National Cancer Institute. PRAME wt Allele. NCI Thesaurus. Code C127929.

Human PRAME wild-type allele is located in the vicinity of 22 q11.22 and is approximately $12 \mathrm{~kb}$ in length. This allele, which encodes melanoma antigen preferentially expressed in tumors protein, is involved in transcriptional repression. Aberrant expression of the gene is associated with melanoma and some acute leukemias. 